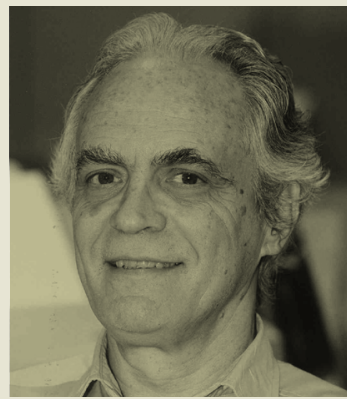

\title{
A DÍVIDA, A TATUAGEM E A CRISE ECONÔMICA
}

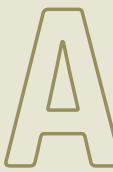

tatuagem dura mais que o amor, assim como as dívidas sobrevivem à carcaça de um carro usado. Resultado: a explosão da inadimplência. No primeiro semestre de 2012, os atrasos aumentaram mais de $20 \%$ em relação ao mesmo período de 2011. É a ressaca da farra dos crediários a partir de 2009 que, embora tenha compensado os efeitos da crise internacional, não foi acompanhada pelo aumento dos investimentos, os quais são essenciais para a expansão sustentável da economia. A queda da SELIC ajuda, apesar de contribuir mais para reduzir o custo da dívida pública e alegrar os exportadores com a valorização do dólar do que estimular o investimento, especialmente entre aqueles que enfrentam taxas de juros escorchantes dos bancos em geral e estão fora do círculo de amigos do Banco Nacional de Desenvolvimento Econômico e Social (BNDES).

A expansão da economia brasileira se apoia em uma mesa de três pernas: o consumo interno, o externo (exportações) e os investimentos (internos e externos). São pernas siamesas, e, até certo ponto, interdependentes. O consumo interno pode ser estimulado baixando os preços via queda de impostos, o que tem sido feito com sucesso depois de 2008. O aumento da renda dos mais pobres também ajuda, mas a dinâmica expansionista do emprego e da renda mostra sinais de fadiga. O externo depende da expansão da Ásia, particularmente da China, além da Europa e dos Estados Unidos. Nesse quesito, as coisas não vão bem. Os investimentos internos públicos estão em queda, e os privados dependem de financiamentos a juros civilizados, apesar do banho de loja que os bancos deram em suas taxas, premidos pelo "exemplo" do Banco do Brasil e da Caixa Econômica Federal, que ainda são estratosféricas. Os investidores externos estão escaldados com a crise que se agrava na Europa - a Espanha cambaleia - e procuram um lugar seguro para esperar a tempestade passar. No jargão financeiro dos anos 60 , "vão dançar com a irmã", e o melhor salão para isso (ainda) são os títulos do tesouro americano.

O investimento que leva o pomposo nome de formação bruta de capital fixo decresce em 2012 em relação a 2011. As expectativas não são boas e a maioria dos empresários vive delas. Da mesa de três pernas, duas estão mancando: o investimento e as vendas externas (exportações). O produto interno bruto (PIB) de 2012 possivelmente será pior do que o de 2011. Dois fatores podem evitar uma queda maior: a expansão das vendas dos automóveis via redução dos impostos e o estímulo às exportações, com um dólar superior a R \$2,00. 